\title{
DIE BARTHOLOMEUSNAG-VIER HONDERD JAAR $\left.{ }^{2}\right)$
}

\author{
DRS. S. J. BOTHA.
}

Die bloedbad van die Bartholomeusnag 23-24 Augustus 1572 en volgende dae, moet gesien word teen die agtergrond van en ook as 'n deel van die politiek-militêr-godsdienstige stryd in Frankryk tussen die jare 1562 en 1593 . Hoewel hierdie tydperk gewoonlik onderskei word in agt godsdiensoorloë met kort wapenstilstande tussenin ${ }^{2}$ ), was dit in werklikheid een groot burgeroorlog waarin politieke en godsdienstige motiewe die dryfvere was. Die aanleidende oorsake tot die gebeure van die Bartholomeusnag, wat tussen die derde en die vierde oorloë geval het, vorm deel van die voorspel tot en die verloop van die eerste tien jaar van die dertigjarige stryd. Die gevolge van die bloedbad moet weer gesoek word in die verloop van die laaste twintig jaar en die naspel van die stryd. Om die Bartholomeusnag in perspektief te kan sien, sal die stryd in sy geheel dus onder oë geneem moet word.

As hier gepraat word van 'n politiek-militêr-godsdienstige stryd, dan is dit baie belangrik om in gedagte te hou dat in daardie tyd politiek en geloof gesien is as sake wat onlosmaaklik aan mekaar verbonde was. 'n Owerheid wat neutraal gestaan het ten opsigte van geloofsake was onbekend en vir geeneen van die strydende partye aanvaarbaar nie ${ }^{3}$ ). Dit kan wel betoog word dat die stryd tussen die hervormde geloof en die roomse geloof 'n geestelike stryd moes wees, wat met ooreenkomstige wapens gevoer moes word, feit is egter dat vanweë die noue saamgaan van politiek en geloof „werd de geloofstrijd onvermijdelijk ook een strijd om de politieke macht tussen roomsen en hervormden, waarin het geloofsmotief voortdurend met andere, politieke en dynastieke beweegredenen gepaard ging"').

Ook in Frankryk was dit nie anders nie, sodat baie moeilik bepaal kan word watter motiewe, politiek of godsdienstig, die vernaamste dryfvere was van die stryd tussen die jare 1562 en 1593.

1) Lesing gehou by die kongres van die Kerkhistoriese Genootskap van die Nederduitsch Hervormde Kerk, 22 November 1972.

2) J. N. Bakhuizen van den Brink en J. Lindeboom, Handboek der Kerkgeschledenis, Deel II, tweede druk, 'S Gravenhage 1946, blz. 156.

3) Selfs die vervolgde Hugenote wou geen godsdiensvryheid nie. Vgl. A. A. van Schelven, Het Calvinisme Gedurende Zijn Bloeitijd, Amsterdam 1943, blz. 152. Vgl. ook H. Berkhof, Geschiedenis der Kerk, Vyfde druk, Nijkerk 1950, blz. 203.

4) H. Berkhof, a.w., blz. 203. 
Die stryd het ook 'n militêre sy gehad waar van wapengeweld gebruik gemaak is deur die strydende partye. Hier moet egter in gedagte gehou word dat militêre optrede in werklikheid steeds maar politiek is, waar net van ander middele gebruik gemaak word.

In Frankryk was die verpolitisering van die geloofstryd nie alleen nadelig en selfs noodlottig vir die Calvinistiese Hugenote nie $^{5}$ ), maar het ook die roomse party op die lang duur in werklikheid die onderspit gedelf teen die koninklike absolutisme wat so kenmerkend van Frankryk geword het ${ }^{6}$ ). Die strewe na die absolute gesag van die koning, wat reeds vroeg in Frankryk ontstaan het, is deur die gebeure tussen 1562 en 1593 'n belangrike stoot vooruit gegee. Dit veral vanweë die optrede van Catharina de Medici, wat op 'n baie behendige maar tog ook dubbelhartige wyse die Roomses en Hugenote teen mekaar afgespeel het, met die doel om die troon veilig te stel en ook haar eie posisie te verstewig. Sy was in werklikheid as 'n derde party by die stryd betrokke en haar optrede sal ook besien moet word.

Die voorspel tot die stryd het veral tussen die jare 1559 en 1562 afgespeel. In die jare het die geloofstryd en die politiekestryd in Frankryk met mekaar verbonde geraak en het die onderskeie partye hulle duidelik teenoor mekaar afgegrens. Die gebeure van hierdie jare sal daarom noukeurig nagegaan moet word. As noodsaaklike agtergrond sal die politiek-godsdienstige situasie tussen 1515 en 1559 ook kortliks nagegaan moet word, omdat in díe jare die elemente wat deel van die stryd sou uitmaak, na vore gekom het.

\section{DIE POLITIEK-GODSDIENSTIGE SITUASIE IN FRANKRYK TUSSEN 1515 EN 1559:}

Gerieflikheidshalwe kan hierdie tydperk in twee verdeel word om saam te val met die regeringstydperke van die twee Franse konings Frans I (1515-1547) en sy seun Hendrik II (1547-1559).

\section{Frans I:}

Wat hierdie tydperk aanbetref is dit van belang om op die volgende te let:

a. Reeds by die begin van Frans I se regering is 'n belangrike fondamentsteen gelê op die weg na die latere koninklike obsalutisme. Trouens, reeds voor Frans I was Frankryk al die grootste enkele nasionale staat in Europa en het die regeringsisteem al

5) Waar die benaming Hugenote vandaan kom is nie seker nie. Vgl. A. A. van Schelven, a.w., blz. 129, voetnoot 3.

6) J. Chambon, Geschiedenis eener Martelaarskerk, vertaal deur $\mathbf{P}$. van der Kraan, Goes 1951, blz. 6 vv.; vgl. ook John T. McNeill, The History and Charaeter of Calvinism, New York 1967, p. 237. 
die eerste tekens begin toon van die absolute koningskap ${ }^{7}$ ). Op hierdie basis het Frans I voortgebou en het hy in 1516 met die Konkordaat van Bologne daarin geslaag om die Roomse Kerk in Frankryk aan hom onderworpe te maak, waardeur hy 'n tussenposisie tussen die pous en die Franse clerus bekom het. Volgens hierdie ooreenkoms het die aanstelling van die clerus in Frankryk nou by die Franse koning berus en moes die kerk ook aan die koning allerlei belasting betaal' ${ }^{8}$ ). Hiermee het die Franse koning geweldig veel mag oor die Roome Kerk in Frankryk bekom en was dit nie die kerk wat die koning vir sy doeleindes kon gebruik nie, maar andersom. Persone wat 'n kerklike amp begeer het of wou behou het nou gewedywer om die guns van die koning, wat op sy beurt weer gelei het tot groter verval van die kerk in Frankryk, aangesien persone wat nie toegerus of bevoeg was nie op die manier hoë kerklike ampte bekom het ${ }^{9}$ ).

Aan die ander kant was dit tog weer vir die Franse koning, vanweë die besondere inkomste wat hy uit die kerk gekry het, belangrik dat die Roomse Kerk ook in Frankryk sterk en ongeskonde sou bly. Dit het Frans II teen die kerkhervorming in Frankryk laat kies omdat 'n belangrike bron van inkomste vir hom bedreig voorgekom het, eerder as wat godsdienstige motiewe sy keuse bepaal het. Trouens, dit moet opgemerk word dat geeneen van die Franse konings na Frans I besonder godsdienstig was nie en ook beslis nie fanatiek rooms soos wat Filips II van Spanje byvoorbeeld was nie ${ }^{10}$ ).

So sterk het Frans I reeds sy posisie gesien dat hy onder al sy edikte die slotsin "Car tel est notre plaisir" (want so is ons behae) kon plaas as teken van die soewereine gaedkeuring van die koning ${ }^{11}$ ). Met bogenoemde in gedagte kan wel betoog word dat hy in 'n sekere sin die grondlegger van die latere koninklike absolutisme genoem kan word ${ }^{12}$ ). Van belang is dit om hier te noem dat die latere sogenaamde „Politiques”; waaronder Catharina de Medici ook gereken moet word, juis by hierdie nasionalistiese en absolutistiese gedagtes aangesluit het met hulle beginsel van neutraliteit van die staat teenoor die godsdienstige partye.

b. Vanweë die sterk nasionalisme in Frankryk het Frans I hom instaat beskou om met Spanje in konflik te tree oor NoordItalië. Hierdie buitelandse politiek het daartoe gelei dat Frankryk voortdurend in oorlog verkeer het met Spanje. Hierdie toestand

7) John T. McNeill, l.c., p. 237.

8) John McNeill. L.c. p. 238.

8) John T. McNeill, L.c., p. 238.

10) Vgl. Roland Bainton, The Reformation of the Sixteenth Century, London 1965, p. 161.

11) J. Chambon, a.w., blz. 12.

12) J. Chambon, a.w., blz. 12. 
het voortgeduur onder Hendrik II. Beide Frans I en Hendrik II kon as gevolg daarvan nie hulle volle aandag aan interne landsprobleme, soos byvoorbeeld die opkoms van die kerkhervorming, gee nie $\left.^{13}\right)$.

c. Die weg vir die reformasie is in Frankryk veral voorberei deur die geleerde humanis Jacques Lefebre d'Etaples (Faber Stapulensis (1455-1536) wat reeds so vroeg as 1512 in kommentare op die briewe van Paulus die gedagte van die regverdiging deur die geloof alleen uitgespreek het $\left.{ }^{14}\right)$. Hy het egter steeds hierdie gedagtes verbind aan die Roomse leer insake goeie werke. Verder het hy ook 'n volledige Bybelvertaling in Frans besorg. $\mathrm{Na} 1520$ het Luther se werke ook in Frankryk bekend begin word en is dit gretiglik gelees. Spoedig was daar oral in Frankryk groepe hervormingsgesindes, met die te Meaux, waar die eerste protestantse gemeente met Pierre LeClerq as predikant gestig is, die bekendste ${ }^{15}$ ). Na die verskyning van die Institutio Christianae Religionis van Johannes Calvyn in 1536, het die Calvinistiese reformasie in Frankryk begin toeneem en teen 1546 was dit so stewig gewortel dat nie meer van „Lutheriens" gepraat is nie $\left.{ }^{16}\right)$. Dit is interessant om daarop te let dat die anabaptisme nie in Frankryk as beweging voorgekom het nie ${ }^{1 i}$ ).

d. Aanvanklik het Frans I, wat self sterk deur die humanisme beinvloed is, van die humaniste wat heelwat evangeliese simpatieë gehad het, soos d'Etaples en andere, beskerm ${ }^{18}$ ). Selfs aan die koninklike hof is hervormingsgesindes aangetref. Veral die koning se suster, Marguerite d'Angoulême, het sterk simpatieë in die rigting getoon en haar hofprediker Gerard Roussel het in evangeliese trant gepreek terwyl sy selfs by geleentheid aan die bekende Guillaume Farel beskerming verleen het ${ }^{19}$ ).

Hoewel in 1523 die eerste hervormingsgesinde in Parys verbrand is, was daar tog aanvanklik geen grootskaalse en georganiseerde vervolging nie $^{20}$ ). $\mathrm{Na} 1533$ het Frans I se houding egter verander ${ }^{21}$ ) en is die vervolgings verskerp. Talle vlugtelinge moes Frankryk nou as gevolg van hulle geloof verlaat, waaronder ook die jong Johannes Calvyn. Teen die einde van Frans I se

13) John T. McNeill, l.c., p. 237; Vgl. ook J. Bakhuizen van den Brink e.a., a.w., blz. 147vv.

14) J. Chambon, a.w., blz. 22.

15) J. Chambon, a.w., blz. $27 v v$.

10) J. Chambon. a.w., blz. 44.

17) Roland Bainton, l.c., p. 95 ff. and $160 \mathrm{ff}$.

18) J. Chambon, a.w., blz. 31 .

19) J. Chambon, a.w., blz. 31 .

20) J. Chambon, a.w., blz. 25.

21) Die aanbring van plakkate, waarin die Roomse mis aangeval is, tot selfs in die koninklike paleis in Parys, het Frans I groot ergernis verskaf en veel daartoe bygedra dat hy teen die hervormingsgesindes begin optree het. 
regering het die vervolgings selfs 'n hoogtepunt bereik toe in 1546 die Waldense te Cabrieres en Merindol bykans uitgewis is en ook die predikant Pierre LeClerq saam met veertien van sy gemeentelede verbrand is $^{22}$ ).

\section{Hendrik II:}

Hendrik II het die buitelandse beleid var sy vader voortgesit en het behalwe teen Spanje ook nog teen Engeland oorlog gevoer ${ }^{23}$ ). Teenoor die hervormdes het Hendrik weliswaar 'n sterker houding ingeneem en selfs die belofte gemaak dat hy die kettery sou uitwis. Met die oog hierop het hy 'n spesiale hof, die sogenaamde „La Chambre Ardente" in die lewe geroep ${ }^{24}$ ). Die aantal arrestasies en teregstellings het vinnig vermeerder en dit wou voorkom of Hendrik sy voorneme sou deurvoer. Sy buitelandse politiek wat vir hom vele oorloë meegebring het, het verhinder dat hy al sy aandag aan die saak kon gee.

Onder sy regering het daar nou adelike families na vore gekom, wat later 'n belangrike rol sou speel in die politiek-godsdienstige stryd. Die eerste was die fanatiek Roomse familie De Guise, met Francois, hertog van Lotharingen en sy broer Carel, kardinaal van Lotharingen, die leiers. Hulle het voortdurend probeer om hulle invloed aan die koninklike hof uit te brei en het hulle oog op die Franse troon gehad. Tesame met figure soos maarskalk De Montmerency en die latere maarskalk St. André, is hulle deur Hendrik as sy raadgewers gebruik ${ }^{25}$ ).

Die ander familie wat na vore gekom het was die huis De Bourbon, wat in „den bloede" ook aan die Franse koning verwant was. Hulle was egter die hervormde geloof toegedaan. Hoof van hierdie huis was Antoine de Bourbon, koning van Navarre (15181562). Hy was egter van wankelmoedige karakter en het nie veel vir die saak van die Calviniste beteken nie. Sterker was sy broer Louis, hertog van Condé, was vanaf 1560 tot 1568 aanvoerder van die Hugenote sou wees. 'n Heel besondere figuur in hierdie kring egter was die edele Jeanne d'Albret, dogter van die reeds genoemde Marguerite d'Angoulême en eggenote van Antoine de Bourbon. Sy het beslis vir die hervormde geloof en die Hugenote saak gekies en tot haar dood standvastig by haar keuse gebly ${ }^{26}$ ).

Intussen het die Calvinisme, gesteun en bemoedig deur hierdie genoemde en ook ander figure uit die adel wat tot hulle geledere toegetree het, vinnig vooruitgegaan, selfs tenspyte van die verskerpte vervolgings. Teen 1555 was daar oral in Frankryk sterk

22) J. Chambon, a.w., blz. 33 en vgl. ook John T. McNeill, l.c., p. 244.

23) J. N. Bakhuizen van den Brink e.a., a.w., blz. 148.

24) J. Chambon, a.w., blz. 45.

25) J. Bakhuizen van den Brink e.a., a.w., blz. 148.

26) Antoine het om politieke redes in 1562 tog weer Rooms geword. Sien A. A. van Schelven, a.w., blz. 151 en 170 . 
Calvinistiese gemeentes, selfs in die fanatiek Roomse Parys. In Parys het veral drie predikante gearbei naamlik Jean le Maçon, Francois de Morel en Antoine de Chandieu (Sr.). In 1557 is 'n eerste geloofsbelydenis van agtien artikels opgestel, vermoedelik deur Chandieu, terwyl in 1558 'n klein aantal predikante te Poictiers 'n aantal ,articles politiques pour l'Eglise reformé”, 'n kerkorde dus, opgestel het ${ }^{27}$ ). Wat getalle aanbetref, het Calvyn in 1558 geskat dat sowat driehonderdduisend van sy volksgenote in Frankryk tot die hervormde godsdiens behoort het ${ }^{28}$ ).

Samevattend kan nou oor die tydperk 1515-1559 die volgende gestel word:

1. Hoewel beide Frans I en Hendrik II teen die hervormdes gekies het, was dit nie soseer omdat hulle vir die roomses gekies het nie. Dit bly 'n ope vraag of die vernaamste dryfveer by hulle keuse politiek of godsdienstig van aard was. Dit was vir hulle immers juis ook om politieke redes baie belangrik, vanweë hulle posisie teenoor die Roomse Kerk en die inkomste wat hulle uit die bron verkry het, dat die Roomse Kerk sterk en ongeskonde sou bly. Hier is dit ook van belang om daarop te wys dat beide selfs by die Lutherse vorste van Duitsland hulp gesoek het teen die roomse Spanje ${ }^{28}$ ).

2. Die hervormdes het in die tyd geen regte gehad nie, maar is vervolg. Hulle was 'n martelaarskerk wat slegs met die wapens van belydenis en lyding geopereer het en was nie 'n party in die politieke sin van die woord nie $^{30}$ ).

3. Die buitelandse politiek van beide Frans I en Hendrik II, wat hulle voortdurend besig gehou het met oorloë teen veral Spanje, het aan die hervormdes tog ietwat meer beweegruimte gegee, wat hulle ook deeglik gebruik het.

4. Die navore kom van die Roomse huis De Guise en die Calvinistiese huis De Bourbon, het die weg gebaan dat by eventuele botsing tussen hierdie twee huise, die geloofstryd in Frankryk verbonde geraak het met die politieke stryd tussen hierdie twee partye.

\section{DIE POLITIEKE EN GODSDIENSTIGE GEBEURE IN FRANK- RYK TUSSEN 1559 EN 1562}

Gedurende hierdie jare het baie belangrike gebeure plaasgevind wat groot verandering in Frankryk teweeggebring het en wat die grondslae gelê het vir die stryd wat sou volg.

1. In April 1559 is daar te Cateau-Cambrésis finaal vrede gesluit tussen Spanje en Frankryk en het Frankryk afstand gedoen

27) J. Bakhuizen van den Brink e.a., a.w., blz. 150 .

28) A. A. van Schelven, a.w., blz. 135 .

29) J. Bakhuizen van den Brink e.a., a.w., blz. 89 .

30) A. A. van Schelven, a.w., blz. 126-156. 
van sy aansprake op Italië en Spanje se leierskap erken ${ }^{31}$ ). Dit het nou meegebring dat weer 'n verenigde Roomse front teen die Protestantisme gevorm is, met die fanatiek Roomse Filips II van Spanje as die politieke hoof van die Roomse mag. Filips II het nou sy hande vry gehad om in die Nederlande teen die hervormdes aldaar te gaan optree, terwyl Hendrik II ook in Frank. ryk allerlei maatreëls begin tref om die hervormde godsdiens ook daar uit te roei ${ }^{32}$ ). Voordat Hendrik II se maatreëls behoorlik in werking kon tree, is hy in Julie 1559 oorlede.

Baie belangrik is hier ook die feit dat, om die vrede van Cateau-Cambrésis te verseël, Elisabeth (1545-1568), die dogter van Hendrik II, op 22 Junie 1559 met Filips II in die huwelik getree het ${ }^{33}$ ). Dit het 'n baie groot invloed vir Filips II aan die Franse koninklike hof verseker en vir baie jare het sy skadu oor die optrede teen die Hugenote in Frankryk geval ${ }^{34}$ ). Voortdurend het hy vervolging teen die Hugenote aangehits en by hom was groot vreugde toe die gebeure van die Bartholomeusnag aan hom berig is.

Na die dood van Hendrik II het sy vyftienjarige seun Frans II, wat getroud was met Maria Stuart koningin van Skotland, koning geword. Vir die huis De Guise het nou 'n geleentheid aangebreek waarop hulle gewag het. As ooms van Maria Stuart het hulle nou die regering van Frankryk namens haar minderjarige eggenoot waargeneem. Dit het hulle egter in botsing laat kom met die De Bourbons, aan wie die regentskap regtens toegekom het ${ }^{35}$ ). Anders as die huis De Guise, het die De Bourbons nie hulle oog soseer op die Franse troon self gehad nie, maar hulle was nie gediend met die groot seggenskap en invloed van die De Guises aan die Franse hof nie. Hoewel Frans II slegs sowat 'n jaar lank koning was, sou die politieke stryd tussen die De Bourbons en die De Guises rondom die Franse troon voortduur en by hierdie politieke stryd het die Hugenote en Roomses in hulJe geloofstryd betrokke geraak. In een opsig egter was hierdie adelike families dit met mekaar eens, naamlik dat hulle beide nie tevrede was met die toenemende mag van die koning nie ${ }^{s 6}$ ).

Die eerste botsing het vir die De Bourbons 'n terugslag beteken toe 'n sameswering van 'n aantal hervormdgesinde edelliede om koning Frans II in Maart 1560 te Amboise te ontvoer en hom so aan die invloed van die De Guises te onttrek, as gevolg van

31) J. Bakhuizen van den Brink e.a., a.w., blz. 148 .

32) A. A. van Schelven, a.w., blz. 159.

33) J. Bakhuizen van den Brink e.a., a.w., blz. 151 .

34) J. Bakhuizen van den Brink e.a., a.w., blz. 156.

35) J. Bakhuizen van den Brink e.a., a.w., blz. 151 .

36) A. D. Pont, Ongepubliseerde Kerkgeskiedenisaantekeninge, bl. 100. 
verraad misluk het. Dit het 'n groot aantal van die samesweerders hulle lewe gekos, terwyl Antoine de Bourbon en sy broer De Condé ternouernood ontkom het ${ }^{37}$ ). Die politieke stryd en geloofstryd was egter nou nie meer te skei nie. Terloops kan daarop gewys word dat ongeveer van hierdie tyd af na die Calviniste van Frankryk verwys is as die Hugenote ${ }^{38}$ ).

2. Na die vrede te Cateau-Cambrésis het talle van die teruggekeerde militêre hulle met die saak van die Hugenote vereenselwig. Die vernaamste onder hulle was seker Admiraal Gaspard de Coligny, uit die Franse adelhuis van Chattilon, wat as oortuigde Calvinis uit sy gevangeskap te Sluis teruggekeer het ${ }^{39}$ ). Hierdie verwikkeling het meegebring dat aan die een kant die Calvinisme se aansien verhoog is en die getalle uit die adel wat daartoe oorgegaan het aansienlik versterk is, terwyl dit aan die ander kant daartoe meegewerk het dat die Hugenotekerk sy martelaarskarakter van voor 1559 bykans plotseling verloor het en nou nie alleen 'n politieke inslag gekry het nie, maar ook vermilitariseer geraak het ${ }^{40}$ ). Dit het uiteindelik daarop uitgeloop dat die Hugenote die Christelike strydmiddels van belydenis en lyding verruil het vir die swaard.

Aanvanklik was De Coligny teen die gebruik van geweld, waarskynlik onder die invloed van Calvyn. Reeds voor die sameswering van Amboise het Calvyn al aan De Coligny, wat wel nie direk by die sameswering betrokke was nie, geskryf om teen geweld te waarsku. Veelbetekenend het hy aan De Coligny geskryf:

„Die eerste druppel bloed wat ons mense vergiet, sal 'n vloedgolf tevoorskyn roep wat die hele Europa sal oorstroom"41).

Op die lang duur egter het De Coligny tog die swaard opgeneem, veral ook op aandrang van sy eggenote wat hom aangespoor het daartoe om sy talente as militaris te gebruik ter beskerming van die goeie saak van die Hugenote ${ }^{42}$ ). Daarmee egter het die Hugenotisme 'n rewolusionêr-politieke kleur gekry.

Dit bring natuurlik die groot vraag na die reg van opstand teen die koning of owerheid na vore. Calvyn het van meet af gewaarsku teen die gebruik van geweld. De Coligny en sy medestanders het dit egter gestel dat hulle nie teen die koning self

37) J. Chambon, a.w., blz. 54.

38) Sien voetnoot 5.

39) A. A. van Schelven, a.w., blz. 160.

40) A. A. van Schelven. a.w. blz. 156.

11) A. D. Pont. a.w., bls. 102 . Reeds op 19 April 1556 het Calvyn al in 'n skrywe na Frankryk gesê: „Overigens, omdat ik gehoord heb, dat verscheidenen uwer overwegen, of zij - indien met hen komt beleedigen - niet maar liever tegenstand zullen bieden, dan zich te laaten berooven, bid ik u, zeer geliefde broeders, zulke plannen te laten varen, want God zal die nooit zegenen". Sien A. A. van Schelven, a.w., blz. 154 en 339.

42) J. Chambon, a.w., blz 61 vv. 
wou optree nie, maar inteendeel dat hulle juis die koning en sy beslissings wou beskerm teen die party van die De Guises. Hulle het hulle ook beroep op die Institutio Christianae Religionis (IV,20.3), waar Calvyn onder sekere omstandighede die reg van opstand aan die laere magistrate gegee het. Nie alle Hugenote het hulle mèt die gebruik van geweld vereenselwig nie. Trouens verskeie sinodes van die Hugenotekerk het hulle selfs baie sterk teen al die bloedvergieting uitgespreek ${ }^{43}$ ).

3. In 'n ander opsig was die jaar 1559 ook vir die Calvinistiese Kerk van Frankryk van baie groot betekenis. Van 25 tot 29 Mei van dié jaar het die eerste sinode van die Franse Kerk te Parys vergader onder die voorsitterskap van Francois de Morel. Op hierdie sinode is 'n behoorlike kerkorde, die „Discipline ecclesiastique”, en 'n belydenis, die „Confession de foi", wat albei op Calvyn teruggegaan, vir die hele Franse Protestantse Kerk aanvaar $\left.{ }^{44}\right)$. Daarmee is die kerkverband vir die Franse Kerk gekonstitueer en kon die lewe van die kerk nou ordelik gereël word. Hierdie gebeurtenis was op die lang duur vir die Franse Kerk van groter betekenis as alle ander van dieselfde tyd, juis omdat die eie duidelike belydenis en behoorlike kerkorde grootliks daartoe bygedra het dat die kerk en sy lidmate weerbaar sou wee:; teen al die aanslae en vervolging ${ }^{45}$ ).

4. Na die dood van Frans II op 5 Desember 1559, het sy tienjarige broer Karel IX koning geword met sy moeder, Catharina de Medici, as regentes. Karel IX was egter 'n totale swakkeling en hoewel hy in 1563 meerderjarig verklaar is, het Catharina die regering behou tot by sy dood in $1574^{46}$ ). Die huis De Guise het nou wel hulle direkte invloed aan die Franse hof verlnor, maar het tog nog leiers van die Roomse party gebly en het steeds hulle oog op die Franse troon gehad.

Nou het daar 'n derde party, dié van die sogenaamde „Politiques", waartoe ook Catharina gereken moet word, na vore begin kom. Hulle was almal nog wel goed Rooms, maar sou miskien as liberale roomses beskryf kon word. Die vernaamste woordvoerder van hierdie groep was die kanselier van Frankryk, Michel de l'Hôpital. Enersyds het hy dit verdedig dat die koninklike mag op goddelike reg gegrond is en andersyds het hy gepleit dat beide vorms van Christendom getolereer moes word en hy wou dat die denominasies ,lutherians, huguenots en papistes" afgeskaf

43) A. A. van Schelven, a.w., blz 187 .

4) J. Bakhuizen van den Brink e.a., a.w., blz. 150.

45) Vgl. byvoorbeeld in hierdie verband wat die belydenis en kerkorde in die Nederlandse Kerk vir die weerbaarheid van die kerk en sy lidmate beteken het.

46) Sien J. Chambon, a.w., blz. 55. 
moes word ${ }^{4 i}$ ). Hoewel die teorieë nuut en onaanvaarbaar vir die tyd was, het dit tog, danksy Catharina de Medici wat in haar optrede daar nou by aangesluit het, 'n rol begin speel.

Catharina wat sterk onder die invloed gestaan het van die leerstellings van haar Italiaanse landgenoot Nicollo Machiavelli, wat in sy „Il Principe" die staat as 'n magsblok beskryf het, het baie nou probeer aansluit by die gedagtes van toleransie van die "Politiques". Daarmee het sy op die oog gehad om aan die een kant die spanning te verlig en die invloed van die De Guises te neutraliseer en om aan die anderkant die koningskap vir haar eie huis veilig te stel en haar eie posisie te verstewig ${ }^{48}$ ) Aanvanklik het sy daarom probeer om die Roomses en Hugenote met mekaar te versoen en daartoe het sy die hou van 'n godsdiensgesprek te Poissy in 1561 toegestaan. Versoening van die twee partye het egter onmoontlik geblyk ${ }^{40}$ ). Verder het sy 'n hele reeks toleransie edikte uitgevaardig waardeur sy die Hugenote al meer gunstig teenoor haar gestem het. Hulle het nou selfs die verwagting begin koester dat die martelaarsperiode vir hulle verby was en hulle was bereid om op versoek van Catharina vir haar die wapen op te neem $\left.{ }^{50}\right)$. By geleentheid het sy selfs sover gegaan om te kenne te gee dat sy graag 'n gesprek sou wou voer met 'n hervormde predikant en sy het ook by geleentheid van Theodorus Beza raad gevra ${ }^{51}$ ). Die verste het sy egter gegaan met die taleransie-edik van St. Germain van Januarie 1562, waarvolgens die Hugenote erkenning ontvang het en die reg om hulle godsdiensoefeninge in die openbaar te hou, behalwe in die versterkte stede $^{52}$ ).

Catharina was egter besig om 'n dubberhartige rol te speel. Aan die een kant het sy met die Hugenote onderhandel en hulle deur genoemde maatreëls teenoor haar gunstig probeer stem, terwyl sy tog aan die anderkant aan die pous laat weet het dat sy en die koning weldra op die ketters sou toeslaan en hulle sou uitwis ${ }^{53}$ ). Haar dubbelhartigheid het ook na vore gekom toe sy slegs 'n maand na die Edik van St. Germain nie alleen die hou van 'n reformatoriese preek aan alle adelike howe verbied het nie,

47) J. Bakhuizen van den Brink e.a., a.w., blz. 154 .

48) Roland Bainton, l.c., p. 167 en 242.

49) Roland Bainton, 1.c., p. 167.

50) A. A. van Schelven, a.w., blz. 168-173.

51) A. A. van Schelven. a.w.. blz. 169.

52) A. D. Pont. a.w., bis. 101.

53) Catharina het vroeg al die Hugenote 'n slag toegedien toe sy op slinkse wyse Antoine de Bourbon en Louis de Condé se huwelike verwoes het. Daarmee het sy veral gesorg dat die sterk invloed wat Jeanne d'Albret op haar eggenoot kon he, wat vir Catharina gevaarlik kon wees, uitgeskakel is. Vgl. J. Chambon, a.w., blz. 56 en A. A. van Schelven, a.w., blz. 193. 
maar ook selfs elke gesprek oor die nuwe geloof $\left.{ }^{54}\right)$. Hierdie dubbelhartige rol het Catharina dwarsdeur die hele stryd bly speel en dit was ook by die gebeure van die Bartholomeusnag op die spel.

Samevattend kan oor die tydperk 1559 tot 1562 die volgende opgemerk word:

a. Gedurende hiendie tyd het die geloofstryd in Frankryk onlosmaaklik met die politieke stryd verbonde geraak en die klimaat vir die stryd is geskep. Drie partye het hulle nou van mekaar onderskei naamlik die Roomse party onder leiding van die De Guises, die Hugenote met De Condé en De Coligny as leiers en Catharina de Medici met haar dubbelhartige rol om die twee partye teen mekaar af te speel.

b. As gevolg van die verpolitisering van die geloofstryd het die martelaarskarakter van voor 1559 uit die Hugenotisme verdwyn en het 'n nuwe gees vaardig geword wat, ten spyte van alle besware, bereid was om na die swaard te gryp.

c. Die groot en belangrike gebeurtenis dat die Hugenote Kerk nou 'n eie behoorlike kerkorde en belydenis gekry het, is totaal oorskadu deur ander gebeure.

\section{DIE VERLOOP VAN DIE STRYD TOT 1572 EN DIE BARTHO- LOMEUSNAG}

Soos te begrype, was die Roomses verontwaardig en woedend oor Catharina se houding van toleransie teenoor die Hugenote. Buitelands het Spanje, die pous, die hertog van Savoye en andere begin dreig om militêr in te gryp in Frankryk om die protestantisme daar uit te roei ${ }^{55}$ ). Binnelands het die Roomse adel hulle rug op die koninklike hof gekeer, terwyl Roomse predikers die gedagte begin verkondig het: ,als blijkt, dat een souverein de kettery begunstigt, heef de Pous het recht diens onderdanen van hun eed van trouw te ontslaan; en; als er een prins van den bloede te vinden is, bereid om daarby de leiding te nemen, mag het volk zijn plicht om te gehoorzamen voor outomaties vervallen houden"se).

Tot daadwerklike optrede het die Roomse gekom toe Francois de Guise, De Montmerency en St. André in Februarie 1562 'n driemanskap gevorm het met die doel voor oë om 'n einde te maak aan die bevoorregte posisie van die Hugenote en ook die kettery te stuit. Reeds in Maart 1562 begin hulle met die uit-

54) A. A. van Schelven, a.w., blz. 173.

s5) A. A. van Schelven, a.w., blz. 169.

s6) A. A. van Schelven. a.w., blz. 169. 
voering van hulle voorneme as Francois de Guise eers te Vassy en daarna te Sens 'n Hugenote gemeente wat vir erediens vergader het, bykans uitwis ${ }^{57}$ ).

Dit word die direkte aanleiding tot die militêre stryd as die Hugenote leërs opruk onder aanvoering van De Condé, met De Coligny tweede in bevel. Die Hugenote leiers het geargumenteer dat hulle nou die reg gehad het om teen die Roomse op te tree omdat hulle die tolleransie-edik van St. Germain verbreek het en dus ongehoorsaam was aan die vors ${ }^{58}$ ). Tot 1570 is daar drie oorloë gevoer waarin ook buitelandse huurtroepe aan beide kante geveg het, sonder egter dat een van die twee vegtende partye werklik die oorhand oor die ander kon $k^{5}{ }^{59}$ ).

Aan Roomse kant het Francois de Guise reeds tydens die eerste oorlog in 1563 gesneuwel en is hy opgevolg deur sy verbitterde en wraakswerende seun Hendrik de Guise. Ook die Hugenote het hulle aanvoerder Louis de Condé in die derde oorlog verloor. Hoewel Jeanne d'Albret haar jong seun Hendrik van Navarre as leier van die Hugenote aangebied het, het De Coligny egter nou die bevel oorgeneem ${ }^{60}$ ). In elk geval het die Hugenote leërs so sterk gestaan dat met die vrede van St. Germain van Augustus 1570, redelik gunstige voorwaardes van die Roomses beding kon word. Behalwe die vier stede La Rochelle, Montauban, Cognac (Navarre) en La Charité het die Hugenoteadel ook nou volkome godsdiensvryheid ontvang en is verder in elke distrik van Frankryk twee plekke aan die Hugenote afgestaan waar hulle ongehinderd hulle godsdiensoefeninge kon $\left.h u^{61}\right)$. Met hierdie vrede was die roomse party geensins tevrede nie en het hulle dadelik, met Hendrik de Guise vooraan, planne begin bedink om dit weer ongedaan te kry.

Intussen het Filips II van Spanje al groter druk op Catharina begin uitoefen om streng teen die Hugenote op te tree $^{62}$ ). Dit het haar onrustig begin maak dat Spanje militêr sou ingryp in Frankryk en dan sou die koningskap vir haar huis verlore wees, aangesien Filips II nie ongeneë was om Hendrik de Guise op die Franse troon te sien nie $^{63}$ ). Nuwe planne moes daarom beraam word. 'n Huwelik is gereël tussen Hendrik van Navarre en Marguerite de Valois, dogter van Catharina, om die vrede van St. Germain te beseël. Na hierdie huwelik is De Coligny en ook

5i) A. A. van Schelven, a.w., blz. 174

58) A. D. Pont, a.w., bls. 102.

59) J. Bakhuizen van den Brink e.a., a.w., blz. 156.

60) J. Bakhuizen van den Brink e.a., a.w., blz 157.

61) J. Bakhuizen van den Brink e.a., a.w., blz. 157.

62) Horace F. MacEwen, The Saint Bartholomew's Day Massacre, artikel in The Reformation Review, Volume XX. Number 1, p. 12.

63) J. Bakhuizen van den Brink e.a., a.w., biz. 156. 
ander vername leiers van die Hugenote genooi, met die gevolg dat 'n hele paar duisend Hugenote in Parys saamgetrek het $\left.{ }^{6 t}\right)$. Slegs ses dae nadat die huwelik op 18 Augustus 1572 bevestig is, het die moordparty op die Hugenote begin. Die bevel tot hierdie moord is gegee deur Karel IX self, maar wel op aanstigting van Catharina en Hendrik te Guise ${ }^{65}$ ).

Of die gedagte aan so 'n massamoord reeds by die reël van die huwelik by Catharina aanwesig was en dat sy dit daarom so vooruit beplan het, is nie duidelik nie en val ook moeilik te bewys. Die betoog dat dit 'n spontane uitbarsting van die Roomse bevolking van Parys was wat geïrriteerd was vanweë die teenwoordigheid van die duisende Hugenote, moet egter ook verwerp word aangesien dit duidelik ' $n$ beplande moord was $^{66}$ ). Ook die agterna-verklaring van die Franse regering dat die Hugenote besig was met 'n sameswering wat die veiligheid van die staat in gevaar gestel het en wat optrede teen hulle noodsaaklik gemaak het, kan nie aanvaar word nie $\left.{ }^{6 i}\right)$. Miskien sou die saak so gerekonstrueer kon word:

Die dubbelhartige Catharina was gedurig bedag daarop dat nie een van die adellike families te veel invloed oor die koning sou bekom en sodoende haar posisie sou verswak nie. Na die vrede van St. Germain het sy bemerk dat De Coligny se invloed op Karel IX al meer begin toeneem het. By die aankoms van De Coligny in Parys vir die hoë huwelik het hy spoedig daarin geslaag om volkome die vertroue van die koning te wen en het hy selfs probeer om Karel IX te oorreed om Franse hulp te ver. leen aan die Nederlandse Geuse teen Spanje. Hierin het Catharina nou ' $n$ bedreiging vir haar en haar huis gesien. Sy het besef dat hulp aan die Geuse kon meebring dat Filips II militêr sou ingryp in Frankryk en dit sou dan aan die gunstelinge van Filips II, die De Guises, 'n gulde geleentheid bied om die Franse troon in die hande te kry. Daarom het sy met die maar al te gewillige Hendrik de Guise saamgesweer om die leier van die Hugenote, De Coligny, te laat vermoor.

Op 22 Augustus het twee aanslae op De Coligny se lewe misluk, hoewel hy in die hand en arm verwond is. Hoewel dit nie vir hulle duidelik was wie die aanslae beplan het nie, het dit tog by Hugenote adel te Parys en ook by Karel IX groot verontwaardiging en agterdog uitgelok. Karel IX, sy moeder Catharina en die hertog van Anjou het nog dieselfde dag van die aanslae op De Coligny by hom gaan besoek aflê en hulle spyt oor

64) Aเ A. van Schelven, a.w., blz. 193.

65) Roland Bainton, l.c., p. 170.

68) A. D. Pont, a.w., bls. 105.

6r) A. A. van Schelven, a.w., blz. 191. 
die gebeure uitgespreek. Die koning het selfs belowe dat hy snel sou optree teen die vermeende skuldige, 'n sekere Maurevel $\left.^{68}\right)$. Weer eens het De Coligny by Karel IX aangedring om hulp vir die Nederlanders teen Filips II van Spanje. De Coligny het sy vors vertrou, en by Karel was daar blykbaar tog ook 'n geneentheid teenoor die admiraal.

Catharina het egter nou besef daar haar posisie in groot gevaar verkeer het en van hierdie geleentheid het Hendrik de Guise gretiglik gebruik gemaak om 'n massamoord aan te stig. Saam het hulle Karel IX oortuig dat die Hugenote vir hom 'n bedreiging ingehou het en hy het toegestem dat die Hugenote adel om die lewe gebring kon word. Haastig is die planne agtermekaar gekry en daar is afgespreek dat die klok van die St. Germain-L'Auxerrois kerk gelui sou word as teken dat die moord moes begin ${ }^{69}$ ).

Intussen het die protestantse adel ook met mekaar beraadslaag en stemme het opgegaan dat hulle dadelik Parys moes verlaat. De Coligny en sy skoonseun Teligny het egter gemeen dat die koning vertrou moes word en hulle het probeer om die gemoedere te kalmeer. 'n Klein getal van die adel het tog besluit om Parys te verlaat en het ook dadelik vertrek ${ }^{70}$ ).

Gedurende die voornag van 23-24 Augustus is die Roomse burgers van Parys byeengebring en is dit aan hulle voorgehou dat ' $n$ Hugenotesameswering teen die koning, sy familie en die Roomse godsdiens ontdek is. Dit het hulle opgesweep vir die bloedbad wat sou volg ${ }^{71}$ ). Om twee-uur Sondagoggend 24 Augustus 1572 het Karel IX persoonlik opdrag gegee dat die klok gelui moes word. Toe die eerste skoot val het Karel 'n boodskapper gestuur dat nie voortgegaan moes word met die plan nie. Dit was egter te laat en die moordparty was reeds in volle swang en kon nie meer gekeer word nie ${ }^{22}$ ).

Een van die eerstes wat geval het was die edele De Coligny, wat ten spyte daarvan dat hy gewaarsku was en ten spyte van die aanslag op sy lewe twee dae tevore, nog soveel vertroue gehad het in die koning dat hy nie wou glo dat die koning so 'n massamoord sou toelaat nie. Die sowat tweehonderd Hugenote edelliede wat in die koninklike paleis gehuisves was, is na buite gesleep en in stukke gekap ${ }^{73}$ ). Die res van daardie nag asook dwarsdeur die hele dag van die vier en twintigste is die afgryslike misdaad in Parys voortgesit en in die volgende dae het dit ook

68) Horace F. MacEwan, l.c., p. 16.

09) Vgl. ook die gebeure direk voor die Bartholomeusnag. A. A. van Schelven, a.w., blz. 192.

тo) Horace F. MacEwan, l.c., p. 16

i1) Horace F. MacEwan, l.c., p. 17.

72) Horace F. MacEwan, l.c., p. 17.

${ }^{73)}$ Horace F. MacEwan, l.c., p. 18. 
uitgebrei dwarsdeur die hele Frankryk. Na raming het tussen 30000 en 45000 Hugenote in hierdie bloedbad gesterf $f^{i 4}$ ). Hendrik van Navarre, die jong bruidegom, en Hendrik de Condé, seun van Louis de Condé, se lewe is wel gespaar, maar onder dwang het hulle Rooms geword.

In Madrid en in Rome was daar groot vreugde en Filips II en pous Gregorius XIII het hulle gelukwensinge aan Karel IX gestuur. Die pous het selfs spesiale dankprosessies laat hou en ook pennings laat slaan om die gebeure in gedagte te hou ${ }^{75}$ ). In die protestantse lande was daar skok en verbystering oor hierdie gruweldaad. Aan die Engelse hof is die berig met afkeur verneem; te Geneve is op voorstel van Beza 'n algemene vasdag uitgeroep wat jaarliks herhaal moes word. Die Skotse Hervormer John Knox, het met sy laaste kragte nog van die preekstoel af die oordeel en wraak uit die hemel Karel IX en sy huis aangesê $\hat{e}^{7 \epsilon}$ ).

\section{DIE GEVOLGE VAN DIE BARTHOLOMEUSNAG}

Vir die Hugenote in die besonder, vir Frankryk in die geheel, maar ook vir Catharina de Medici en haar huis, het die bloedbad ernstige en verreikende gevolge gehad.

Die moord het vir die Hugenotisme, beide wat sy omvang en struktuur aanbetref, vérstrekkende gevolge gehad. Wat getalle aanbetref het die Hugenote sterk verminder. Al die vernaamste leiers uit die adel is om die lewe gebring, ander het gevlug na onder andere die kanaaleilande Jersey en Guernsey, terwyl 'n derde groep na die Roomse Kerk teruggekeer het ${ }^{77}$ ). Ook duisende Hugenote uit die laere stande het ter wille van hulle lewe die land uitgevlug. Dit het tot gevolg gehad dat nie alleen die getalle van die Hugenote aanmerklik verminder het nie, maar ook dat die adelike vleuel daarvan bykans geheel en al verdwyn het. Die gewone burgerry het nou die krag in die Hugenotisme geword. In 'n sekere sin was dit in geestelike en religieuse opsig 'n suiweringsproses, maar sosiaal gesproke het die Hugenotisme sy aansien verloor $\left.{ }^{78}\right)$.

Die verandering van gees wat daar in die Hugenotisme gekom het na die gebeure van die Bartholomeusnag, het veral op twee maniere na vore gekom:

1. In die eerste plek het hulle 'n radikaler anti-koninklike gesindheid vertoon $\left.{ }^{79}\right)$. Voorheen het hulle hulle veral gerig teen diegene wat die troon omrig het as raadgewers en hulle vyandig

74) Selfs 'n getal van 70000 word genoem. Sien John T. McNeill, l.c., p. 248.

75) Horace F. MacEwan, 1.c., p. 20.

76) Horace F. MacEwan,l.c., p. 21.

i7) A. A. van Schelven, a.w., blz. 193-4.

78) A. A. van Schelven, a.w., blz. 194-5.

i9) A. A. van Schelven. a.w., blz. 195. 
gesind was, soos onder andere die De Guises, terwyl hulle tog lojaal teenoor die koning gebly het. Nou het hulle hulle egter teen die koning self gerig en het hulle die afsetbaarheid van die koning en die reg van opstand teen sy tirannie verkondig en verdedig. In hierdie verband kan gewys word op twee publikasies wat van die hand van Hugenote skrywers verskyn het.

Die eerste publikasie was die van die juris Francois Hōtman wat in 1573 sy "Franco-Gallio" die lig laat sien het ${ }^{80}$ ). Hy skryf die hele ongelukkige stryd in Frankryk toe aan die feit dat afgewyk is van die oorspronklike beginsel dat die koningskap nie erflik was nie, maar waar die koning deur die volk gekies is. Verder voeg hy daarby die verderflike invloed van vreemdes soos veral die Italiane aan die koninklike hof. Sy oplossing was daarom dat daar teruggekeer moes word na 'n kiesryk en 'n suiwer Franse regering.

Groter invloed het die tweede publikasie gehad, wat die titel "Vindiciae contra Tyronnos" gedra het en in 1579 onder die pseudoniem Stephanus Brutus Celta verskyn het ${ }^{81}$ ). Na aanleiding van vier vrae is die gedagtes in verband met die reg van opstand teen ' $n$ tirannieke koning volledig behandel. Die teokratiese gedagtes van Calvyn is in hierdie werk vermeng met die natuurregtelike opvatings van die soewereiniteit van die volk. Ook is klem gelê op die gedagte van die verbond of covenant wat sou bestaan tussen God en die koning en God en die volk. Hiervoor is 'n beroep gedoen op 2 Kon. 11:17: „En Jojada het die verbond gesluit tussen die Here en die koning en die volk, dat hulle 'n volk van die Here sou wees; ook tussen die koning en die volk."

Die volgende aanhaling uit die Vindiciae spreek in hierdie verband duidelik: „The covenant is double between God and the king and between God and the people. Each is bound to see that the church be not damnified. If Israel forsake God and the king makes no account of it, he is justly guilty of Israel's delinguency. In like manner if the king follows after strange gods and Israel seek not to withdraw him from his rebellion, they make the fault of their king their own transgression. But who may punish the king if it be not the whole body of the people to whom the king swears and obliges himself no more and no less than do the people to the king" ${ }^{82}$ ).

Aan die een kant het hy verklaar dat hy onder die volk, wat teen die koning moes optree, diegene verstaan het wat deur die

so) A. A. van Schelven, a.w., blz. 195.

81) A. A. van Schelven, a.w., blz. 196 .

82) Aangehaal by Roland Bainton, 1.c., p. 240. 
volk as tussengangers tussen hulle en die koning gekies is, naamlik die laere magistrate ${ }^{\mathrm{s} 3}$ ).

Aan die ander kant het hy egter tog nie teruggedeins van die konsekwensie ,dat, wanneer in geval van onderdrukking de door de wet aangewezen optimaten zich niet opmaakten, bij wijze van achterban het volk self naar de wapenen macht grijpen"84).

2. 'n Tweede saak waarin die verandering van gees van die Hugenotisme na die Bartholomeusnag na vore gekom het, was 'n kragtige strewe om hulle nou politiek te organiseer ${ }^{55}$ ). Naas die gewone kerklike vergaderings, is ook nog andere in die lewe geroep soos die "Conseils provincianx" en "assembleès" wat, hoewel in verband met kerk en godsdiens, wesenlik politiek van aard was. Hulle het dit hulle ten doel gestel om te ywer vir vryheid van godsdiensoefening, benoembaarheid van Hugenote in alle offisiële ampte, 'n eie regspraak vir die Hugenote en die besit van 'n paar pandstede in elke provinsie van Frankryk.

Reeds op 6 Mei 1576 kon hulle te Beaulieu in meeste van hierdie sake heelwat konsessies van koning Hendrik III afdwing. In 1598 is meeste van hierdie beginsels met die Edik van Nantes bevestig en het die Hugenote in werklikheid 'n staat binne 'n staat geword $^{86}$ ).

Met hierdie verandering van gees in die Hugenotisme na 1572 het dit egter duidelik geword dat dit nou vir hulle nie meer moontlik was om, wat die geloofstryd betref, hulle terug te trek op die suiwere geestelike lyn nie. Daarom moes die stryd noodwendig voortgaan en is na die Bartholomeusnag nog vyf oorloë tot 1593 geveg wat die totale dodetol vir die dertig jaar vanaf 1562 tot 1593 op digby een miljoen te staan sou bring. Hiendie voortdurende oorloë en bloedvergieting het die moontlikheid vir die protestantisme om die volksgeheel te beinvloed ${ }^{87}$ ) hoe langer hoe meer uitgeskakel.

Vir Frankryk as staat was hierdie langdurige stryd ook rampspoedig. Afgesien van die feit dat duisende van die talentvolste burgers van Frankryk die lewe gelaat het, het dit die land op die rand van bankrotskap gebring. Nòg die Roomses nỏg die Hugenote kon werklik 'n volslae oorwinning behaal, terwyl 'n hele ent gevorder is op weg na die koninklike absolutisme wat in Lodewyk XIV verwerklik is en wat later vir Frankryk nog groot bitterheid sou meebring ${ }^{88}$ ).

83) Roland Bainton, l.c., p. 240.

81) A. A. van Schelven, a.w., blz. 197.

85) A. A. van Schelven, a.w.. blz. 198.

86) A. A. van Schelven, a.w., blz. 198-9.

87) A. A. van Schelven, a.w., blz. 201.

88) J. Chambon, a.w., blz. 12 en 229 vv. 
Ook vir Catharina de Medici en die huis van Valois het die Bartholomeusnag en die oorloë daarna nederlaag gebring. Van die kant van die Hugenote kon sy geen steun of vertroue meer verwag nie. Haar dubbelhartigheid was te opsigtelik. Ook Filips II van Spanje het haar gewantrou en sy kandidaat vir die Franse troon was Hendrik de Guise.

Wel kon sy nog 'n derde seun van haar op die Franse troon sien in Hendrik III wat vanaf 1574 tot 1589 regeer het. Hy het weliswaar daarin geslaag om die gevaar van die De Guises te elimineer toe hy in 1588 Hendrik de Guise laat vermoor het ${ }^{89}$ ). Toe Hendrik III egter in 1589 self die slagoffer van moord geword het, het die Franse troon na die De Bourbons gegaan, toe Hendrik van Navarre. koning Hendrik IV van Frankryk geword het $\left.{ }^{90}\right)$.

Hoewel Hendrik IV met Marguerite de Velois getroud was, is hy van haar geskei en toe getroud met Maria de Medici, uit wie sy opvolger Lodewyk XIII gebore is ${ }^{91}$ ). Catharina se nageslag het daarmee die Franse troon verloor.

Aan die anderkant was die feit dat 'n De Bourbon koning geword het tog nie vir die Hugenote 'n oorwinning nie. Hendrik van Navarre, wat in 1572 onder dwang Rooms geword het, het wel weer teruggekeer tot die Hugenote en ook in verskeie oorloë hulle leërs aangevoer ${ }^{92}$ ).

Tog het hy, toe hy koning van Frankryk geword het getoon dat die Franse troon vir hom belangriker was as sy geloofsoortuigings en het hy in 1593 weer Rooms geword om Parys in besit te kon neem ${ }^{93}$ ).

Vir die Hugenote wat baie van hom verwag het was dit 'n bittere teleurstelling. Hy het nie sy voorgangers se beleid van vervolging voortgesit nie, maar het met die toleransie Edik van Nantes aan die Hugenote vele vryhede en regte toegestaan. Daarmee het hy egter getoon dat hy ook tot die sogenaamde „Politiques" gereken moet word $\left.{ }^{94}\right)$. Blykbaar is dit dan ook net die „Politiques" wat na die stryd van dertig jaar op enige sukses kon aanspraak maak.

89) J. Chambon, a.w., blz. 80 .

90) Roland Bainton, l.c., p. 171.

91) J. Bakhuizen van den Brink e.a., a.w., blz. 153.

92) J. Bakhuizen van den Brink e.a., blz. 160.

93) J. Chambon, a.w., blz. 82.

94) Roland Bainton, l.c., p. 171-2. 


\section{SLOTOPMERKINGS}

Nou agterna gesien was dit 'n baie ongelukkige gebeurtenis dat die geloofstryd in Frankryk met die party-politieke stryd verbonde geraak het. Nog jammerder is dit dat die Hugenote ook tot wapengeweld oorgegaan het. Dit alles het die Calvinisme in Frankryk tot nadeel gestrek. Dit het morele en sedelike verval in die hand gewerk en die Calvinisme sy aansien laat verloor.

Aan die ander kant moet die geloofstandvastigheid van vele duisende, wat tenspyte van al die bloedvergieting en ten spyte van die bloedbad soos die Bartholomeusnag, tog aan die evangelie trou gebly het, deur ons bewonder en nagevolg word. 